\title{
ДИСТАНЦІЙНА ДОДИПЛОМНА МЕДИЧНА ОСВІТА: МІФ ЧИ РЕАЛЬНІСТЬ? ЗАВДАННЯ ТА ПЕРСПЕКТИВИ
}

Т. А. Хомазюк, В. І. Гриценко, Ю. П. Люлька

\author{
Д3 “Дніпропетровськамедична академія МОЗ Украӥни”
}

\section{DISTANCE PRE-GRADUATE MEDICAL EDUCATION: MYTH OR REALITY? CHALLENGES AND PROSPECTS}

\author{
T. A. Khomazyuk, V. I. Hrytsenko, Yu. P. Lyulka \\ SI "Dnipropetrovsk Medical Academy of MPH of Ukraine"
}

\begin{abstract}
Стаття присвячена питанням актуальності впровадження дистанційної додипломної освіти у сфері медицини. Протягом останніх десятиліть у медичній освіті стрімко розвиваються комп'ютерні технології, які можуть мати практичне значення не тільки в аудиторній роботі зі студентами, але насамперед у позааудиторній самостійній підготовці. Дано визначення терміну дистанційної освіти, перелічено можливі засоби дистанційної освіти щодо клінічних дисциплін. Наведені приклади дистанційної освіти в Німеччині, США, проаналізовано позитивні аспекти даної форми навчання. Доведено, що дистанційна форма не поступається та суттсво доповнюс і оптимізус традиційну форму навчання.
\end{abstract}

The article is devoted to the actual implementation of distance pre-graduate education in medicine. During the last decades computer technology is rapidly developing in medical education that can have practical value not only in the audience or clinic work with the students but above all things outside in independent preparation. Determination of term of the distance education was given, possible facilities of the distance education were transferred in relation to clinical disciplines. The examples of distance education in Germany, USA were resulted, the positive aspects of this form of education were analyzed. It is well-proven that the distance form does not yield but substantially complements and optimizes the traditional form of studies.

Вступ. Освіта - це динамічний процес, який вимагає постійного вдосконалення як студента, так і викладача. Використання сучасних інформаційних технологій (в першу чергу-персональних комп'ютерів, Інтернету, мультимедіа) дозволяє вивести процес навчання на якісно більш високий рівень $[1,3,7,8]$.

На сьогодні широко обговорюються питання впровадження дистанційного навчання на різних рівнях освіти: середній, середній професійній, вищій за різноманітними напрямками підготовки. Комп'ютер й Інтернет у сучасній освіті - це спосіб оволодіння не тільки теоретичними знаннями, але й практичними навичками $[2,10,15]$.

Основна частина. Напевне, найбільше суперечок викликає дистанційне навчання спеціалістів у галузі медицини $[4,15]$. Зараз існують численні тлумачення цієї методології у навчальному процесі. Що саме мають на увазі під дистанційною освітою? Чи можливо навчати студента-медика дистанційно? Як це позначиться на якості його підготовки? Щоб з'ясувати це питання, доречно проаналізувати розвиток даного напрямку.

Більше ста років тому деякі європейські університети розпочали проводити навчання за листуванням.
Студент поштою отримував підручники та завдання. В подальшому розпочиналось листування, під час якого студент консультувався, ставив запитання викладачеві та отримував на них відповіді. 3 часом пошту замінили інші канали зв'язку: телефон, телеграф, факсимільний зв'язок, а в доповнення до підручників стали використовуватися аудіозаписи та відеофільми $[9,11,16]$.

Дистанційне навчання (теленаставництво) - різновид навчального процесу, при якому або викладач i аудиторія, або учень і джерело інформації розділені між собою географічно $[1,4,13]$.

На сьогодні до засобів дистанційного навчання відносяться:

- електронні підручники;

- сітьові навчально-методичні посібники;

- комп'ютерні навчальні системи в звичайно-

му і мультимедійному варіантах;

- аудіоматеріали навчально-інформаційного змісту;

- відеоматеріали навчально-інформаційного змісту;

- лабораторні дистанційні практикуми;

- тренажери з віддаленим доступом; 
- електронні бібліотеки з віддаленим доступом;

- засоби навчання на основі експертних навчальних систем.

Противники впровадження дистанційного навчання в медицині часто наводять таку тезу: а чи можливо дистанційно навчити людину щось “робити руками”? Адже професія лікаря багато в чому полягає у виконанні різного роду операцій і маніпуляцій $[6,14]$.

У відповідь на це можна навести приклад підготовки льотчиків. Перш ніж сісти за штурвал літака, вони проходять не тільки курс теоретичної підготовки, але й відпрацьовують свої дії на тренажерах і симуляторах.

Прикладом є і медична освіта в Німеччині, де безпосередня робота 3 пацієнтом планується і дозволяється не на 4 семестрі навчання, як в Україні, а тільки після успішно складених іспитів теоретичної підготовки на 7-10 семестрах навчання [5].

У США було проведено дослідження, де взяли участь 97 лікарів поліклінічної ланки 3 передмістя X' юстона, які були рандомізовані у дві групи: перша - навчалась інтерактивно в рамках декількох сеансів 3 використанням Інтернету, друга - навчалась за допомогою звичайного інтерактивного семінару [12]. Рівень знань лікарів оцінювали до початку дослідження, відразу після завершення занять і через 12 тижнів. За 5 місяців до навчання і через 5 місяців після закінчення навчання оцінили кількість пацієнтів з груп високого ризику, яких лікували відповідно до рекомендацій національних керівництв.

За результатами дослідження, опублікованими в журналі Американської медичної асоціації (JАMA), обидва підходи до навчання забезпечили однакові знання досить високого рівня у лікарів як відразу, так і через 12 тижнів після закінчення дослідження. Порівняно 3 результатами до навчання рівень знань підвищився на 31 \% відразу по завершенні навчання та на 36,4 \% через 12 тижнів після закінчення дослідження. Не відзначалося значної різниці при скринінгу пацієнтів в обох групах. Однак в групі дистанційної освіти відзначалося значне збілышення частки пацієнтів, яким призначили лікарську терапію відповідно до посібників (90,3 \% vs 85,3 \%; p=0,04). Незначне зменшення цього показника виявили в семінарській групі.

Таким чином, дане дослідження є одним з перших доказів того, що в доповнення до традиційної освітньої підготовки лікарів дистанційна освіта за допомогою Інтернету може також поліпшити практику лікування пацієнтів. Зрозуміло, що навчання лікаря практичних навичок вимагає традиційного очного контакту, але вся теоретична підготовка та вправи у прийнятті рішень можуть проходити в дистанційній формі. Для того щоб правильно розподілити час навчання на дистанційну і традиційну “фази”, немає необхідності в переробці навчального плану. Слід лише правильно сформувати інформаційний блок у форматі модульного робочого плану для самостійної роботи студентів-медиків та забезпечити доступ до Інтернет-ресурсу в зручних місцях користування (читальні зали навчальних корпусів, гуртожитків, інтернеткафе), а також сформувати потребу до використання цього ресурсу “заліковими балами” - балами, які отримує студент за індивідуальну роботу на сайті.

Для освоєння клінічних дисциплін особливе значення має забезпечення студентів якісними відеоматеріалами навчально-інформаційного змісту (тематичні майстер-класи), комп'ютерними навчальними системами в мультимедійному варіанті (фототеки діагностичних симптомів з питаннями і аналізом правильних відповідей), тренажери у віддаленому варіанті (покрокові алгоритми дій), засоби навчання на основі експертних навчальних систем (клінічний розбір тематичних історій хвороби з аналізом семіотики, синдромальної діагностики, формуванням нозологічної гіпотези і плану обстеження відповідно до діючих стандартів надання медичної допомоги). Істотну роль раціонально сформований Інтернет-ресурс відіграє в ознайомленні студентів, мотивованих в освоєнні клінічних дисциплін, з можливостями як рутинних, так i сучасних (неінвазивних і інвазивних) додаткових методів дослідження структурно-функціонального стану органів і систем, на що, як правило, не вистачає часу практичного заняття. Даний методологічний підхід до інтеграції клінічної та дистанційної форм навчання студентів медичних вузів дозволяє вирішувати і проблему “святкових" і “кліматичних" позапланових канікул, що становлять у різні роки від 10 до $17 \%$ аудиторного навчального часу (i більше для іноземних студентів 3 кліматичною дезадаптацією) з втратою діалогу викладач - студент у рамках планового програмного навчання.

Досвід роботи в такому режимі самостійної підготовки студентів 3 основ діагностики в клініці внутрішніх хвороб (на додаток до практичних занять 3 хворими в клініці) дозволяє вважати дану форму підготовки студентів досить ефективною і доцільною для оптимізації засвоєння не тільки знань, але й умінь як в інтерв'юванні пацієнтів (моделювання оптимізації опитування), так і дотриманні алгоритмів фізикального обстеження, впевненості дій і чіткості техніки виконання маніпуляцій. Про це свідчать дані моніторингу думки студентів про підвищення рівня 
засвоєння матеріалу (67 \% опитаних), формування професійного інтересу і мотивації до збільшення часу самостійної підготовки з дисципліни до 50-60 \% (34-х годин на тиждень). Рівень успішності студентів, які використовували Інтернет-ресурс у самостійній підготовці з дисципліни, на 23 \% вище однокурсників, які не використовували можливості отримання додаткової інформації та тренінгу. Перспективним напрямком є розвиток інтерактивного діалогового

\section{Література}

1. Казаков В. Н. Дистанционное обучение в медицине / В. Н. Казаков, В. Г. Климовицкий, А. В. Владзимирский. Донецк : ООО “Норд”, 2005.-80 c.

2. Кошелев И. А. Дистанционное образование в системе современного здравоохранения: реальность и перспективы/ И. А. Кошелев // Медицинский альманах. -2010. - № 1. - C. $48-53$.

3. Мур М. Г. Общие роли, навыки и умения, требуемые в дистанционном обучении / М. Г. Мур // Information and Communication Technologies in Distance Education. Specialized Training Course. - UNESCO, 2002.-P. 66-69.

4. Пуговкин А. П. Использование системы дистанционного обучения ELEARNING SERVER для программированного контроля в медицинском образовании / А. П. Пуговкин, С. В. Агапонов // Новые технологии в медицине : сб. докл. Первой международной дистанционной науч.-практ. конф.-СПб., 2004. - С. 92-94.

5. Шкарин В. В. Медицинское образование в Германии / В. В. Шкарин // Нижегор. мед. журн. -2002. -№2. - С. 127 131.

6. Ali N. Web-based professional education for advanced practice nursing: a consumer guide for program selection / N. Ali, K. Hodson-Carlton, M. Ryan // J.Contin.Educ.Nurs. 2002.-Vol.33(1).-P.33-38.

7. American Center for the Study of Distance Education.http://www.ed.psu.edu/acsde. спілкування студент - викладач в режимі безпосередньої або відстроченої взаємодії ONLINE.

Висновок. Таким чином, актуальність включення Інтернет-ресурсу при вивченні клінічних дисциплін на додаток до традиційної методології вітчизняної терапевтичної вищої медичної школи є безсумнівною, а напрямок потребує подальшої методичної розробки, об'єднання зусиль та обміну досвідом зарубіжних і вітчизняних вищих медичних шкіл.

8. Best Practices of Computer Conferencing in Distance Education / ACSDE Conference Report. - 1996. - 20 p.

9. Curran V. A review of evaluation outcomes of web-based continuing medical education/V. Curran, L. Fleet// Med.Educ. -2005. - Vol. 39(6).-P. 561-567.

10. Grant J. The Flexible Use of Distance Learning in a Professional Context: the Medical Experience /Distance Education Futures. Ted Nunan, ed.- Adelaide: University of South Australia, 1993. - P. 309-329.

11. Farnes N. Analytical survey Distance Education for the Information Society: Policies, Pedagogy and Professional Development. - Moscow, 2000.-86 p.

12. Comparison of the instructional efficacy of Internet-based CME with live interactive CME workshops: a randomized controlled trial / M. Fordis, J. E. King, C. M. Ballantyne [et al.] // JAMA. -2005. - Vol. 294(9).-P. 1043-1051.

13. Competence, continuing education, and computers / $\mathrm{M}$. Hegge, P. Powers, L. Hendrickx, J. Vinson// J.Contin.Educ.Nurs. -2002.-Vol.33(1).-P. 24-32.

14. Web-based virtual microscopy in teaching and standardizing Gleason grading / H. Helin, M. Lundin, J. Lundin [et al.]// Hum.Pathol.-2005. - Vol. 36(4). - P. 381-386.

15. Moore M. Distance Education in the Health Sciences / M. Moore, J. Savrock. - Pennsylvania, 2001. - 123 p.

16. Open and distance learning. Trends, policy and strategy considerations. - UNESCO, 2002. - P. 27-30. 